\title{
Front Matter: Volume 6979
}

, "Front Matter: Volume 6979," Proc. SPIE 6979, Independent Component Analyses, Wavelets, Unsupervised Nano-Biomimetic Sensors, and Neural Networks VI, 697901 (24 April 2008); doi: 10.1117/12.801186

SPIE Event: SPIE Defense and Security Symposium, 2008, Orlando, Florida, SPIE. United States 


\section{PROCEEDINGS OF SPIE}

\section{Independent Component Analyses, Wavelets, Unsupervised Nano-Biomimetic Sensors, and Neural Networks VI}

Harold H. SzU

F. Jack Agee

Editors

17-19 March 2008

Orlando, Florida, USA

Sponsored and Published by

SPIE

Volume 6979 
The papers included in this volume were part of the technical conference cited on the cover and title page. Papers were selected and subject to review by the editors and conference program committee. Some conference presentations may not be available for publication. The papers published in these proceedings reflect the work and thoughts of the authors and are published herein as submitted. The publisher is not responsible for the validity of the information or for any outcomes resulting from reliance thereon.

Please use the following format to cite material from this book:

Author(s), "Title of Paper," in Independent Component Analyses, Wavelets, Unsupervised NanoBiomimetic Sensors, and Neural Networks VI, edited by Harold H. Szu, F. Jack Agee, Proceedings of SPIE Vol. 6979 (SPIE, Bellingham, WA, 2008) Article CID Number.

ISSN 0277-786X

ISBN 9780819471703

Published by

SPIE

P.O. Box 10, Bellingham, Washington $98227-0010$ USA

Telephone +1 3606763290 (Pacific Time) · Fax +1 3606471445

SPIE.org

Copyright (c) 2008, Society of Photo-Optical Instrumentation Engineers

Copying of material in this book for internal or personal use, or for the internal or personal use of specific clients, beyond the fair use provisions granted by the U.S. Copyright Law is authorized by SPIE subject to payment of copying fees. The Transactional Reporting Service base fee for this volume is $\$ 18.00$ per article (or portion thereof), which should be paid directly to the Copyright Clearance Center (CCC), 222 Rosewood Drive, Danvers, MA 01923. Payment may also be made electronically through CCC Online at copyright.com. Other copying for republication, resale, advertising or promotion, or any form of systematic or multiple reproduction of any material in this book is prohibited except with permission in writing from the publisher. The CCC fee code is 0277-786X/08/\$18.00.

Printed in the United States of America.

Publication of record for individual papers is online in the SPIE Digital Library.

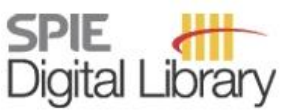

SPIEDigitalLibrary.org

Paper Numbering: Proceedings of SPIE follow an e-First publication model, with papers published first online and then in print and on CD-ROM. Papers are published as they are submitted and meet publication criteria. A unique, consistent, permanent citation identifier (CID) number is assigned to each article at the time of the first publication. Utilization of CIDs allows articles to be fully citable as soon they are published online, and connects the same identifier to all online, print, and electronic versions of the publication. SPIE uses a six-digit CID article numbering system in which:

- The first four digits correspond to the SPIE volume number.

- The last two digits indicate publication order within the volume using a Base 36 numbering system employing both numerals and letters. These two-number sets start with $00,01,02,03,04,05$, 06, 07, 08, 09, OA, OB ... 0Z, followed by 10-1Z, 20-2Z, etc.

The CID number appears on each page of the manuscript. The complete citation is used on the first page, and an abbreviated version on subsequent pages. Numbers in the index correspond to the last two digits of the six-digit CID number. 


\section{Contents}

vii Conference Committee
ix Introduction

\section{SENSORS, BIOMETRICS, AND SECURITY}

697902 Fixed analysis adaptive synthesis filter banks [6979-01]

C. A. Lettsome, Georgia Institute of Technology (USA); M. J. T. Smith, Purdue Univ. (USA);

R. M. Mersereau, Georgia Institute of Technology (USA)

697903 Texture based iris recognition system [6979-02]

H. Mehrotra, P. Gupta, Indian Institute of Technology Kanpur (India); A. K. Kaushik, Ministry of Communication and Information Technology (India)

697904 Sensor performance evaluation analysis of imitation fingerprint [6979-04]

K. YU, H. Lee, Y. Bae, Korea Polytechnic Univ. (South Korea)

697905 A non-cooperative long-range biometric image tracking and recognition (BITAR) method for maritime surveillance [6979-05]

X. Li, Intelligent Automation, Inc. (USA); G. Chen, DCM Research Resources, LLC (USA);

E. Blasch, Air Force Research Lab. (USA); H. H. SzU, T. McKenna, Office of Naval Research (USA)

\section{DIGITAL PROGRAMMABLE LOGIC}

697906 FPGA design of MOMS-based sampling rate converters [6979-06]

U. Meyer-Bäse, Florida State Univ. (USA)

697907 DSP with FPGAs: a Xilinx/Simulink-based course and laboratory [6979-07]

U. Meyer-Bäse, Florida State Univ. (USA); A. Vera, Univ. of New Mexico (USA);

A. Meyer-Bäse, Florida State Univ. (USA); M. Pattichis, Univ. of New Mexico (USA); R. Perry, Florida State Univ. (USA)

697908 Performance evaluation of a FPGA implementation of a digital rotation support vector machine (Invited Paper) [6979-08]

H. Lamela, J. Gimeno, M. Jiménez, M. Ruiz, Univ. Carlos III de Madrid (Spain)

697909 An analogue circuit for sequential minimal optimization for support vector machines (Invited Paper) [6979-09]

M. Jiménez, H. Lamela, J. Gimeno, Univ. Carlos III de Madrid (Spain)

\section{APPLICATIONS IN MEDICINE}

6979 OA Robust stability analysis of the heat shock response in E. coli [6979-10]

A. Meyer-Bäse, R. van Engelen, S. Cappendijk, Florida State Univ. (USA) 
6979 OB West meets East: psychophysics studies for understanding mysterious Oriental health promoting practices [6979-11]

H.-W. Chen, Consultant (USA)

6979 OC Gene regulatory networks simplified by nonlinear balanced truncation [6979-12] A. Meyer-Bäse, Florida State Univ. (USA); F. Theis, Helmholtz Ctr. Munich (Germany)

6979 OD Dependent component analysis applied to lesions' characterization in breast MRI [6979-13] A. Meyer-Bäse, O. Lange, Florida State Univ. (USA); T. Schlossbaver, Ludwig-MaximiliansUniv. München (Germany); A. Wismueller, Univ. of Rochester (USA)

\section{NANOSCIENCE AND NANOTECHNOLOGY}

6979 OE Nanotechnology for aerospace: potential transitions from university research (Invited Paper) [6979-14]

F. J. Agee, Rice Univ. (USA)

6979 OF Plasmon-enhanced terahertz near-field microscopy for nanometer-scale sensing [6979-15] D. Mittleman, V. Astley, H. Zhan, F. Hao, P. Nordlander, F. J. Agee, Rice Univ. (USA)

\section{IP PROTECTION OF ELECTRONICS AND WIRELESS NETWORKS}

$6979 \mathrm{OH} \quad \mathrm{HDL}-$ level automated watermarking of IP cores [6979-16]

E. Castillo, Univ. of Granada (Spain); U. Meyer-Baese, Florida State Univ. (USA); L. Parrilla, A. García, A. Lloris, Univ. of Granada (Spain)

6979 0l Dynamic digital watermark technique based on neural network [6979-17]

T. GU, X. Li, North China Institute of Science and Technology (China)

6979 0J Fuzzy neighborhood filters for UWB range radios in multipath environments [6979-18] K. C. Cheok, Oakland Univ. (USA); G. R. Hudas, J. L. Overholt, U.S. Army TACOM-TARDEC (USA)

NEURAL NETWORKS APPLIED

6979 OL Classifiers utilized to enhance acoustic based sensors to identify round types of artillery/ mortar [6979-20]

D. Grasing, S. Desai, A. Morcos, U.S. Army RDECOM (USA)

\section{IMAGING APPLICATIONS}

6979 OM Using a genetic algorithm to find an optimized pulse coupled neural network solution [6979-21]

R. Edmondson, M. Rodgers, M. Banish, Polaris Sensor Technologies (USA) 
6979 ON Graph theoretic segmentation of airborne lidar data [6979-22]

L. Wang, John Chance Land Surveys, Inc. (USA) and Univ. of Louisiana at Lafayette (USA);

H. Chu, Univ. of Louisiana at Lafayette (USA)

$697900 \quad$ Thresholding for higher-order statistical denoising [6979-23]

S. P. Kozaitis, T. Young, Florida Institute of Technology (USA)

6979 OP The canonical minimised Adder graph representation [6979-24]

U. Meyer-Bäse, Florida State Univ. (USA); O. Gustafsson, Linköping Univ. (Sweden);

A. Dempster, Univ. of New South Wales (Australia)

$69790 Q \quad$ Autonomous mental development with selective attention, object perception, and knowledge representation (Invited Paper) [6979-27]

S.-W. Ban, Dongguk Univ. (South Korea); M. Lee, Kyungpook National Univ. (South Korea)

6979 OR Spatiotemporal sharpening of sub-pixel super-resolution by means of two infrared spectrum cameras for early cancer detection [6979-33]

C.-Y. Lee, H.-Y. Hsieh, S.-C. Lee, National Taiwan Univ. (Taiwan); C.-S. Huang, Y.-C. Chang,

National Taiwan Univ. Hospital (Taiwan); C.-M. Chen, H. SzU, National Taiwan Univ. (Taiwan)

\section{NANOENGINEERING AWARD}

6979 OU Micro- and nano-robotic technologies [6979-35]

T. Fukuda, M. Nakajima, P. Liu, Nagoya Univ. (Japan)

\section{FAST PARALLEL PROCESSING USING GPU AND APPLICATIONS IN SPACE TIME ADAPTIVE} PROCESSING

6979 OV Overview of DARPA MTO GPU program (Invited Paper) [6979-29]

D. Healy, MTO, DARPA (USA); D. Braunreiter, J. Furtek, H.-W. Chen, Science Applications International Corp. (USA)

6979 OW Overview of implementation of DARPA GPU program in SAIC (Invited Paper) [6979-30]

D. Braunreiter, J. Furtek, H.-W. Chen, Science Applications International Corp. (USA);

D. Healy, MTO, DARPA (USA)

6979 OX Advanced image registration techniques and applications (Invited Paper) [6979-31]

H.-W. Chen, D. Braunreiter, Science Applications International Corp. (USA); D. Healy, MTO, DARPA (USA)

Author Index 
Downloaded From: https://www.spiedigitallibrary.org/conference-proceedings-of-spie on 26 Apr 2023

Terms of Use: https://www.spiedigitallibrary.org/terms-of-use 


\title{
Conference Committee
}

\author{
Symposium Chair
}

Larry B. Stotts, Defense Advanced Research Projects Agency (USA)

Symposium Cochair

Ray O. Johnson, Lockheed Martin Corporation (USA)

Program Track Chair

Andrew R. Pirich, ACP Consulting (USA)

Conference Chairs

Harold H. Szu, Office of Naval Research (USA)

F. Jack Agee, Rice University (USA)

Conference Cochair

Fredric M. Ham, Florida Institute of Technology (USA)

Program Committee

Shun-ichi Amari, RIKEN-The Institute of Physical and Chemical Research (Japan)

C. Sidney Burrus, Rice University (USA)

Chang Wen Chen, Florida Institute of Technology (USA)

Wen-Yan D. Chung, Chung Yuan Christian University (Taiwan)

Andrzej S. Cichocki, RIKEN-The Institute of Physical and Chemical Research (Japan)

Ronald A. DeVore, University of South Carolina (USA)

Qian Du, Mississippi State University (USA)

Norden E. Huang, NASA Goddard Space Flight Center (USA)

Phillip Q. Hwang, National Imagery and Mapping Agency (USA)

Joseph Landa, BriarTek Inc. (USA)

Soo-Young Lee, Korea Advanced Institute of Science and Technology

(South Korea)

Te-Won Lee, University of California, San Diego (USA)

William Liou, Western Michigan University (USA)

Kevin W. Lyons, National Institute of Standards and Technology (USA)

Shoji Makino, Nippon Telegraph and Telephone Corporation (Japan)

Anke Meyer-Bäse, Florida State University (USA)

Uwe Meyer-Bäse, Florida State University (USA)

Francesco C. Morabito, Università degli Studi di Reggio Calabria (Italy)

Erkki Oja, Helsinki University of Technology (Finland) 
Dennis W. Prather, University of Delaware (USA)

Hairong Qi, The University of Tennessee (USA)

Mark J. T. Smith, Purdue University (USA)

Wim Sweldens, Lucent Technologies, Bell Laboratories (USA)

Mladen V. Wickerhauser, Washington University in St. Louis (USA)

Donald C. Wunsch II, University of Missouri-Rolla (USA)

Ning Xi, Michigan State University (USA)

Takeshi Yamakawa, Kyushu Institute of Technology (Japan)

Fred Yang, Missioncare Hospital Group (Taiwan) 


\section{Introduction}

The SPIE proceedings Volume 6979, Independent Component Analyses Wavelets, Unsupervised Learning, Nano-Bio-mimetic Sensors, and Neural Networks VI, has a special significance, representing a decade-long history of several new transdisciplines merging together naturally. This synergy can help us design smart sensors for a safer and better home care system for an aging population of baby boomers.

Along with an Office of Naval Research (ONR) ad hoc think tank led by me, Veteran Affairs (VA) has explored ways to establish the degree of user-friendliness for the majority of healthy retirees in their second or third careers, in terms of four known principles: "noninvasive, noncontact, nontethered, and non-stop-tomeasure," in order to collect personalized biomedical data called "wellness baseline profiling (WBP)." These four known rules were derived from retired 60 year-old navy veterans who received routine clinical visits with an attached questionnaire. In a typical breakdown of 60 -year-old seniors, $90 \%$ considered themselves healthy, while $10 \%$ considered themselves to be feeble and/or ill. The cohort statistics viewpoints are distinctly different between the $10 \%$ of seniors who are feeble or ill versus those who are healthy and often in a second career.

Thus, we are the basic group of "jack of all trades." Applied researchers decided to involve, other than the traditional Wavelet Pioneer Award presented during the last 15 years and the Unsupervised Learning ICA Award for the last five years, a new category of Nanoengineering Award related to the nano-robot controlled by the computer-aided design (CAD), such as the automated nano-manipulator, which can produce a reliable productivity beyond 25\%. Moreover, in 2007 we introduced another new category called the Biomedical Wellness (BMW) Engineering Award. The reason behind the incorporation of new award categories is that we must encourage the development of smart pair devices to save the exorbitant cost of health care for the aging population. Federal Reserve Chair Ben Bernanke has warned Congress that federal government fiscal budgets will not be sustainable when all the post-war baby boomers retire (78 million will cost 1/5 1/4 of the GDP in the U.S. alone). We need affordable and effective household devices for the daily sampling of wellness baseline profile to compile unsupervised learning of personnel diagnostic aids: A stitch in time saves nine.

The selection procedure for a qualified recipient is identical to the Wavelet Pioneer Award and the Unsupervised Learning ICA Award. Namely, the new winners of the Nanoengineering Award and the Biomedical Wellness (BMW) Engineer Award will automatically assume the position of next year's chair of the selection committee for the following year's award recipients, and will also participate or replace the next retired committee member as the new member of the committee to select subsequent recipients. In other words, the 
management of the conference shall not be involved in the selection process of awardees, but rather will facilitate the information for the new award recipients who are responsible for giving an extended presentation at the conference, submitting a manuscript for publication in the conference proceedings, organizing/chairing an hour-long panel discussion and a special session, and teaching a short course.

This procedure of separating the honor from the management has maintained the credibility of these awards over the years, and we are sure this will work for these two new awards. This useful education process will ensure that all in attendance can fully benefit from his or her presence at the conference and record in the proceedings and tutorial notes. Also, the money gained from teaching the course can sustain and financially support his or her travel and lodging expenditure. Such a quality assurance will be extended to the NanoEngineering Award and Biomedical Wellness (BMW) Award in 2008.

We look forward to your advice and active participation. We are planning a new "System Biology Award" category; we believe system biology is a new trend of computational intelligence approach to biology, covering nine orders of magnitude: from DNA (SNP) to cells; from molecular signaling to organ; to the wellness physiology. If you would like to contribute to such a specific talk, chair a session, or recommend old or new speakers including yourself, please write the conference management.

Harold H. SzU 